\title{
Beyond Traverse des Sioux: Captain Edwin V. Sumner's Expedition to Devil's Lake in 1845
}

\author{
DURWOOD BALL
}

IN SUMMER 1845, Captain Edwin V. Sumner commanded a squadron of First United States Dragoons on a diplomatic mission that took him from southeastern to far northwestern Iowa Territory just below British Canada. His principal task was to deliver the Canadian Métis a federal prohibition of their annual buffalo hunts on U.S. soil. The region of the upper St. Peter's and Red rivers encompassed a borderland society defined and bound by cultural, economic, and political exchanges among diverse Native, mixed-blood, and Euro-American peoples. ${ }^{1}$ The federal government and its army, however, viewed the area as a geographic and international frontier inhabited by unruly, often lawless peoples ignorant of U.S. territorial limits or defiant toward its national sovereignty. As originally conceived, Sumner's operation was a typical summer tour of Native villages on distant frontiers intended to encourage amity and peace among the Indians and to impress "all with the friendship, the vigilance, and the power of the United States." 2 In that context, Captain Sumner conducted his campaign to inscribe U.S. sovereignty on the land, impress

1. The St. Peter's River is now known as the Minnesota River. For a definition of borderland in this regional context, see David G. McCrady, Living with Strangers: The Nineteenth-Century Sioux and the Canadian-American Borderlands (Lincoln, NE, 2006), 2-4.

2. Major General Winfield Scott describes the standard dragoon operation in his "Annual Report," in U.S. Senate, Report of the Secretary of War, 28th Cong., 2nd sess., 1844-1845, S. Ex. Doc. 1/4, ser. no. 449, p. 130.

THE ANNALS OF IOWA 74 (Winter 2015). (C) The State Historical Society of Iowa, 2015. 
national authority on Native Americans, and assess the military threat posed by the Santee Sioux, Métis, and British in the region.

President James K. Polk's strident expansionism, however, elevated Sumner's expedition and several other army operations deployed that summer to bold projections of U.S. nationalism that directly confronted or challenged British and Mexican power in North America. At his inauguration in early March 1845, Polk promised to "re-annex" Texas ("unwisely ceded away to a foreign power") and to "re-occupy" Oregon ("our title ... is "clear and unquestionable'"). In private, he soon added California, weakly held by Mexico, to his list. The president's guiding principle was the Monroe Doctrine, the U.S. proscription of any new European colonies in the Americas. Polk particularly targeted Great Britain, which had jointly occupied Oregon with the United States since 1818. In the spring of 1845, the British unsuccessfully tried to broker a last-minute peace treaty between Mexico and Texas that would recognize Texas independence, block U.S. annexation of the Lone Star Republic, and thus check American expansion into the Southwest. The Anglophobic Polk, like most American expansionists, saw John Bull as the most formidable imperial impediment to the march of American liberty and national sovereignty across North America to the Pacific Ocean. In Polk's mind, U.S. geopolitical expansion, the rational force of nature, and the will of God equaled human progress-social, economic, and political - of the highest order. ${ }^{3}$

In this contest between empires and nations, Sumner's expedition was no mere summer "excursion" to shoo unwanted Natives from U.S. soil. In fact, army operations, such as Sumner's campaign to the Red River of the North, would be the Polk administration's primary tactical tool for challenging Great Britain and Mexico in North America. Of the five expeditions dispatched

3. Robert W. Merry, A Country of Vast Designs: James K. Polk, the Mexican War, and the Conquest of the American Continent (New York, 2009), 9-10, 131-32; Thomas M. Leonard, James K. Polk: A Clear and Unquestionable Destiny, Biographies in American Foreign Policy no. 6 (Wilmington, DE, 2001), 50-56, 73, 77-78, 80; Daniel Walker Howe, What Hath God Wrought: The Transformation of America, 1815-1848, Oxford History of the United States (New York, 2007), 701-9. Polk's inaugural address is reprinted in James Richardson, ed., A Compilation of the Messages and Papers of the Presidents, 1789-1897, 10 vols. (Washington, DC, 189699), 4:373-82. 
in summer 1845, Sumner's march to Devil's Lake has received the least attention from American historians. The only existing full account of Sumner's expedition frames it generally as an exercise in Indian policy, not as an imperial operation in continental expansion. ${ }^{4}$ The sudden appearance of Sumner's expedition so close to the border, however, unnerved British authorities in Canada and England to the point that its ramifications were discussed in the highest circles of the British ministry in London during a critical stage in its negotiations with the United States over the final division of Oregon.

THE ROOT of Sumner's mission lay in a complaint filed by Amos J. Bruce from the St. Peter's Indian Agency at Fort Snelling in Iowa Territory during late summer 1842. Bruce reported that the "half-breeds" (the Métis) who lived on the Red River of the North in Canada were arming themselves "with three small cannon" to fight any Yanktons, Sissetons, or other Sioux encountered during their "annual incursions" to hunt buffalo south of the international boundary each spring and fall. Bruce accused these "British Red River half-breeds" of trespassing on U.S. soil and Sioux hunting grounds. Their massive slaughter threatened the bison herds, and their intrusions triggered warfare with the Sioux, the Sissetons in particular. Summer drought, crop failures, and game scarcity were already impoverishing and starving the Dakota Sioux on the upper St. Peter's River. The federal government, declared Bruce, was legally and morally obligated to protect them, their territory, and their game from these foreign intruders. ${ }^{5}$

\footnotetext{
4. Nancy L. Woolworth, "Captain Edwin V. Sumner's Expedition to Devil's Lake in the Summer of 1845," North Dakota History 28 (1961), 79-98. Other historians who sketch or mention Sumner's campaign are Louis Pelzer, Marches of the Dragoons in the Mississippi Valley: An Account of Marches and Activities of the First Regiment of United States Dragoons in the Mississippi Valley between the Years 1833 and 1850 (Iowa City, 1917), chap. 11; Francis Paul Prucha, The Sword of the Republic: The United States Army on the Frontier, 1783-1846, Wars of the United States (New York, 1969), 386-88; and Samuel J. Watson, Peacekeepers and Conquerors: The Army Officer Corps on the American Frontier, 1821-1846, Modern War Studies (Lawrence, KS, 2013), 75.

5. Agent Amos J. Bruce to Governor John Chambers, 9/15/1842, St. Peter's Agency, Iowa Territory, in U.S. Senate, Annual Report of the Office of Indian Affairs, 27th Cong., 3rd sess., 1842-1843, S. Ex. Doc. No. 1/7, ser. no. 413, pp. 427-31.
} 
Iowa territorial governor John Chambers, a veteran of frontier campaigns against "British" Indians during the War of 1812, added a dose of frontier Anglophobia. These "hardy and daring" Canadian "half-breeds" - the American and British term for the Métis-secured Sioux acquiescence "with presents of ardent spirits and other articles." Should war with Great Britain erupt, he warned, they would "exercise a dangerous influence over all the Indians on our northwestern border" and "greatly endanger our border settlements." In the meantime, the Métis traded and sometimes skirmished with the Yanktons and Sissetons. Although silent on the Métis in 1843, Bruce and Chambers reissued their protest the following year. Would the U.S. government remonstrate "to Her Majesty's government" and dispatch a "military force" to coincide with the "annual incursions of the halfbreeds" ? Captain Sumner's expedition was the federal government's response to the alarm raised by Bruce and Chambers.

Sumner's mission to far northwestern Iowa was one of five significant U.S. Army deployments that advanced Polk's expansionist agenda in the summer of 1845. To confirm the annexation of Texas, the president ordered Brigadier General Zachary Taylor and some 3,000 regulars to confront enraged Mexican forces at the Rio Nueces in south Texas. Captain John C. Frémont led a topographical unit over the southern Rockies toward California. Frémont detached his assistant, Lieutenant James Abert, at Bent's Fort on the Arkansas River, to survey the Canadian River valley in eastern New Mexico and northern Texas. And Colonel Stephen W. Kearny circumnavigated the central plains with 250 First Dragoons, penetrating deeply into South Pass toward Oregon. ${ }^{7}$

6. "Report of His Excellency John Chambers, Iowa Superintendency," 1842, U.S. Senate, Annual Report of the Office of Indian Affairs, 27th Cong., 3rd sess., 18421843, S. Ex. Doc. No. 1/7, ser. no. 413, pp. 421-24; Gov. John Chambers, "Report on Indian Affairs in the Iowa Superintendency," 9/27/1844, in U.S. Senate, Report of the Office of Indian Affairs, 28th Cong., 2nd sess., 1844-1845, S. Ex. Doc. No. 1/5, ser. no. 449, p. 419; Bruce to Chambers, 9/1/1844, St. Peter's Agency, in U.S. Senate, Report of the Office of Indian Affairs, 28th Cong., 2nd sess., 1844-1845, S. Ex. Doc. No. 1/5, pp. 422-23; Bruce to Chambers, 9/1/1843, St. Peter's Agency, Iowa Territory, in U.S. Senate, Report of the Commissioner of Indian Affairs, 28th Cong., 1st sess., 1843-1844, S. Ex. Doc. 1/5, ser. no. 431, pp. 377-79.

7. U.S. Senate, Report of the Secretary of War, William Marcy, 29th Cong., 1st sess., 1845-1846, S. Ex. Doc. 1/4, ser. no. 470, pp. 193-207; General Winfield Scott, "Annual Report of the Commanding General of the Army," ibid., 208-10; K. Jack 
Like the other four, Sumner's operation assessed foreign influence among the Indians, Native amity or belligerence toward Americans, and regional military threats posed by Mexico or Great Britain, while reconnoitering roads and trails for civilian and military expansion into geographic frontiers.

ON APRIL 9, 1845, as Texans debated the United States' official offer of annexation, Adjutant General Roger Jones gave Colonel Kearny permission to field the two dragoon expeditions, his own and Sumner's, that he had proposed the previous month. Kearny's battalion would proceed from Fort Leavenworth over the Platte River Road to South Pass, turn south to Bent's Fort on the Arkansas River, and return east on the Santa Fe Trail. Four weeks later, Kearny's headquarters ordered Captain Sumner to locate the British "half-breeds" in far northwestern Iowa Territory and instruct them to cease their "intrusions" on U.S. soil. On paper at least, both Kearny's and Sumner's commands would represent the "roving column," the "standard" War Department deployment of dragoons "to prevent Indian hostilities by the exhibition of military force" deep in Native homelands. ${ }^{8}$ The same day that Jones wrote to Kearny, however, the adjutant general also instructed Brigadier General Matthew Arbuckle at Fort Smith, Arkansas, to withhold his dragoons from any "distant

Bauer, The Mexican War, 1846-1848 (1974; reprint, with a new introduction by Robert W. Johannsen, Lincoln, NE, 1992), 18-19; William H. Goetzmann, Army Exploration of the American West, 1803-1863 (New Haven, CT, 1959), 116-27; Tom Chaffin, Pathfinder: John Charles Frémont and the Course of American Empire (New York, 2002), part 5; Dwight L. Clark, Stephen Watts Kearny: Soldier of the West (Norman, OK, 1961), 92-100; Prucha, Sword of the Republic, chap. 18.

8. Kearny pitched the dragoon expeditions two weeks after Polk's inauguration. See Kearny to Adjutant General Roger Jones, 3/18/1845, St. Louis, vol. 1 (1 DMo), Letters Sent, Third Military Department, in Sixth Military Department, 18321853, entry no. 45, part 1, Records of the U.S. Army Continental Commands, 1821-1920, Record Group 393, National Archives, Washington, DC (hereafter cited as vol. 1, 3MD, LS, no. 45, part 1, RG 393, NA); AAAG Henry S. Turner to Sumner, 5/7/1845, St. Louis, ibid; Jones to Kearny, 4/9/1845, Washington, DC, A46, box 3, Letters Received, 1831-48, Sixth Military Department, 1832-53, entry no. 49, part 1, Records of the U.S. Army Continental Commands, 1821-1920, Record Group 393, National Archives, Washington, DC (hereafter cited as LR, [year], 3MD, no. 49, part 1, RG 393, NA). General Scott reiterated this policy in his "Annual Report" for 1844, in U.S. Senate, Report of the Secretary of War, 28th Cong., 2nd sess., 1844-1845, S. Ex. Doc. 1/4, ser. no. 449, p. 130. 
prairie circuits this season"; the government might want them "in Texas." 9 Mexican and British outrage over Polk's Texas and Oregon policies elevated Kearny's and Sumner's dragoon expeditions from routine frontier patrols of Indian country to campaigns of international diplomatic and military significance in North America.

At Fort Atkinson, picturesquely perched on a bluff above Turkey Creek in eastern Iowa Territory, Sumner was a little apprehensive about the disposition of the upper Dakota Sioux. A U.S. infantry guard detail at Fort Snelling had recently wounded a Sioux "steersman" when it fired on canoes "attempting to run a quantity of whiskey up the St. Peters River" to Lake Traverse. Captain Sumner reasoned that the shooting "must have a tendency to make the Indians hostile." On May 4, anticipating the possibility of combat in upper Dakota country, Sumner requested the deployment of infantry from Fort Snelling to guard the rear of his column while it operated deep in Sioux country. In addition, should the "half-breeds or Indians" create "difficulty" for his dragoons, a "surgeon" would provide valuable service to his men. ${ }^{10}$ Kearny assigned the surgeon, but Sumner's squadron operated hundreds of miles in the interior of Dakota country with no infantry screen.

On May 7, prior to receiving Sumner's letter, Kearny's headquarters spelled out the details of the mission. The captain should march his dragoon squadron, consisting of his own Company B and Captain James Allen's Company I, from Traverse des Sioux north along the "St. Peter's toward the North Red River" beyond "Lake Travers [sic]" and make contact with the British "half breeds." Colonel Kearny had three aims in mind: (1) to "warn them [the Métis] of the necessity of confining themselves in the future to their own limits"; (2) to counsel the Sisseton Sioux to keep the peace with the whites and with other Indians; and (3) to survey the country above the Blue Earth River for a "temporary

9. Jones to Arbuckle, 4/9/1845, Washington, DC, A45, 1845, LR, 3MD, box 3, no. 49 , part 1, RG 393, NA.

10. Sumner to AAAG Henry S. Turner, 5/4/1845, Fort Atkinson, S45, 1845, LR, 3MD, box 4, no. 49, part 1, RG 393, NA. Captain Electus Backus reported the shooting in a letter to Turner, 4/23/1845, Fort Snelling, enclosure, K113, 1845, Letters Received, Adjutant General's Office, microfilm, roll 300 (Washington, DC, 1964), Letters Received by the Office of the Adjutant General, Main Series, 182260, Microcopy No. 567, National Archives Microfilm Publications, National Archives (hereafter cited as [letter number], [year], LR, AGO, [roll number], M567). 


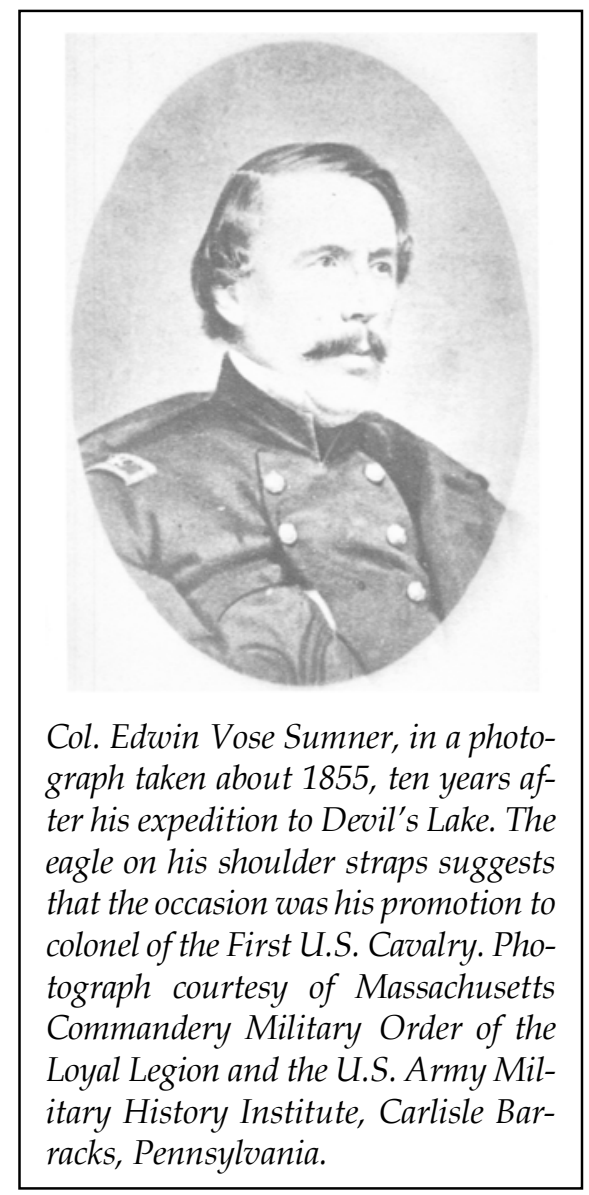

Military Post." Headquarters also enclosed a list of "provisions" warehoused "at Traverse des Sioux" and available to supply Sumner's squadron. ${ }^{11}$

Kearny neither anticipated nor addressed an issue uppermost in Sumner's mind. The previous October, on the upper St. Peter's River, Sumner had arrested five Sisseton Sioux whose war party had allegedly attacked white cattle drovers, scattered or killed their livestock, and murdered one man, "Mr. Watson."

11. AAAG Henry S. Turner to Sumner, 5/7/1845, St. Louis, vol. 1, LS, 3MD, no. 45, part 1, RG 393, NA; AAAG to Allen, 5/7/1845, St. Louis, ibid. Allen's company was posted at Fort Des Moines. 
However, they escaped confinement during the return to Fort Snelling. Did the colonel want Sumner to "demand ... the murderers of Watson" - both the warriors the Sisseton chiefs had never delivered to U.S. authorities and those who were now fugitives? ${ }^{12}$ Preparing for his plains expedition, Kearny left the matter entirely to Sumner's discretion. The Sissetons would likely remember the bellicose, uncompromising Captain Sumner.

The 48-year-old Sumner was an old Iowa hand. Since his first posting there in 1834, he had removed Indians, hunted whiskey peddlers, ejected white trespassers, and reconnoitered the frontier. Wholeheartedly committed to the professional army, he was later described as "old school, rugged and stern, honest and brave ... devoid of sensibility ... a austerely sober." One of Captain Allen's sergeants aptly summed up Sumner's reputation among the dragoons: "all expect to be blown up like the devil." 13 No officer defended federal prerogatives as tenaciously, advanced state power as persistently, and enforced army regulations as vigorously as did Captain Sumner. He demanded of himself an even higher standard of action, devotion, and discipline than he expected of his officers and men. ${ }^{14}$ His experience, courage, and

12. Sumner to AAAG Henry S. Turner, 5/4/1845, Fort Atkinson, S-45, 1845, LR, 3MD, box 4, no. 49, part 1, RG 393, NA; Sumner to AAAG, 3rd Military Department, 5/11/1845, Fort Atkinson, S-45, 1845, LR, 3MD, box 3, ibid.; Kearny to Adjutant General Roger Jones, 9/6/1844, vol. 1, LS, 3MD, no. 45, part 1, RG 393, NA. Lieutenant Colonel Henry Wilson commanded the battalion that invaded Sisseton country. Sumner handed his prisoners over to the custody of Wilson, who lost them. See Wilson to AAAG Henry S. Turner, 10/24/1844, Fort Snelling, enclosure, K139, 1844, LR, AGO, roll 287, M567.

13. For biographies of Sumner, see F. Stanley, E. V. Sumner, Major General, United States Army (1797-1863) (Borger, TX, 1969); William Wallace Long, "A Biography of Major General Edwin Vose Sumner, United States Army, 1797-1963" (Ph.D. diss., University of New Mexico, 1971); and Thomas K. Tate, General Edwin Vose Sumner, U.S.A.: A Civil War Biography (Jefferson, NC, 2013). Stanley and Long briefly narrate Sumner's expedition; Tate omits the operation. The sergeant's assessment is [Anonymous], 1 June 1845, "A Journal of March for the Year 1845," in "The Dragoons in the Iowa Territory, 1845," ed. Robert Rutland, Iowa Journal of History and Politics 51 (1953), 161. Donald C. Pfanz quotes Thomas Claiborne in Richard S. Ewell: A Soldier's Life (Chapel Hill, NC, 1998), 29.

14. William B. Skelton, An American Profession of Arms: The Army Officer Corps, 1784-1861, Modern War Studies (Lawrence, KS, 1992), xiii-xiv; Samuel J. Watson, Peacekeepers and Conquerors: The Army Officer Corps on the American Frontier, 1821-1846, Modern War Studies (Lawrence, KS, 2013), vii-viii, xiii-xv. Skelton and Watson explore the development of professional military culture among 
hardiness would well serve his frontier mission into the homeland of hard-pressed, often angry upper Dakota tribes.

Spring 1845 had been a busy season for Captain Sumner. As he was investigating wagon roads between the Mississippi River and Fort Atkinson, a Native male made "a violent attempt to ravish" a "respectable woman" at the nearby Winnebago agency. On his return, the outraged captain stormed onto the reserve, seized the "barbarous" culprit, and ordered him flogged. The Office of the Adjutant General endorsed the punishment. ${ }^{15}$ The expedition to the Red River of the North would be a break, not entirely unwelcome, from the many nettlesome duties of army service at a frontier post.

SUMNER'S EXPEDITION to the Red River of the North got under way on May 29, when Captain Allen's Company I, with about 57 officers and men, departed the second Fort Des Moines and snaked north along the Des Moines River. ${ }^{16}$ Violent storms

U.S. Army officers during the first half of the nineteenth century. Professionalization was well under way by the 1840s, and Captain Sumner was a significant professional force in the mounted branch.

15. AAAG Henry S. Turner to Sumner, 4/8/1845, St. Louis, vol. 1, LS, 3MD, no. 45, part 1, RG 393, NA; Sumner to AAAG, Third Military Department, 5/12/ 1845, Fort Atkinson, copy, S-159, 1845, LR, AGO, roll 304, M567; Sumner to AAAG, Third Military Department, 5/11/1845, Fort Atkinson, S-45, 1845, LR, 3MD, box 3, no. 49, part 1, RG 393, NA; Assistant Adjutant General Samuel Cooper to Commanding Officer, Third Military Department, 6/12/1845, Headquarters, Western Division, New Orleans, D-45, 1845, LR, 3MD, box 3, no. 49, part 1, RG 393, NA.

16. Kearny's headquarters had instructed Allen to report to Sumner at Traverse des Sioux by June 12. AAAG Henry S. Turner to Allen, 5/7/1845, St. Louis, vol. 1, LS, 3MD, no. 45, RG 393, NA. Allen had graduated from the U.S. Military Academy in 1829 and was promoted to captain of Company I eight years later. He had served on the Iowa frontier since 1842. See George W. Cullum, "James Allen," Biographical Register of the Officers and Graduates of the United States Military Academy at West Point, N.Y.: From Its Establishment, March 16, 1802, to the Army Re-organization of 1866-67, 2 vols. (New York, 1868), 1:355-56. The aggregate of Allen's company is in the table "Position and Distribution of the Troops in the Western Division, under the Command of Brevet Major General Edmund P. Gaines," in U.S. Senate, Report of the Secretary of War, 29th Cong., 1st sess., 1845-1846, S. Ex. Doc. No. 1/5, ser. no. 470, between pp. 220 and 221. Robert W. Frazer, "Des Moines II," Forts of the West: Military Forts and Presidios and Posts Commonly Called Forts West of the Mississippi River to 1898 (Norman, OK, 1965 [1972]), 46-47. 
soaked men, horses, and mules almost daily, and all labored mightily to cross rain-swollen bogs, sloughs, and rivers, and stay upright on slippery prairies. Sumner's Company B, with 56 officers and men, departed Fort Atkinson four days later on June 2. Sumner later reported that "full" streams, "wet" prairies, and muddy roads slowed the northward progress of his men. Companies B and I rendezvoused near Rice Lake on June 13, marched another ten miles, and bivouacked at a "grassy Lake." In camp that evening, the surgeon's assistant wrote in his journal, "All doing well and harmoniously." 17

The next day, Sumner led the squadron north toward Traverse des Sioux. The surgeon's assistant admitted, “Can't but admire the way in which Captain Sumner and Lt. [Leonidas] Jenkins take the water," and praised Company B's two-wheeled "carts." On June 17, the day after the Texas Senate resolved to accept the United States' annexation proposal and reject the British-brokered peace treaty with Mexico, Private Howard of Company I accidentally fired a pistol round that wounded him "above the thigh" and Private Berry "in the knee." The following day, the dragoons hauled their agonizing comrades over a rough trail to the St. Peter's River, where Sumner "embarked" the wounded troopers in "canoes" for Traverse des Sioux. The men's reward that evening was "the fashionable [repast] of the prairies, strawberry punch," mixed from the abundant wild fruit found along their route. ${ }^{18}$

The following day, fording the swollen Le Sueur River tested Sumner's frontier soldiering. The captain sent the wagons, carts, and baggage aboard a mackinaw boat downriver to Traverse des Sioux, while the squadron unsaddled its horses and "swam" them across the river. On June 21, after marching east down the south bank of the St. Peter's, the dragoons again drove their

17. Maj. George Dearborn to Adj. Gen. Roger Jones, 6/2/1845, Fort Atkinson, D102, 1845, LR, AGO, roll 297, M567; [Anonymous], "Journal of March," 5/296/13/1845, pp. 160-63; Sumner to AAAG, Third Military Department, 8/23/ 1845, Fort Atkinson, enclosure, K-113, 1845, LR, AGO, r. 300, M567 (hereafter cited as Captain Sumner's Report); Fort Atkinson, Return, June 1845, microfilm, roll 47 (Washington, DC, 1965), Returns from Military Posts, 1800-1916, Microcopy No. 617, National Archives Microfilm Publications (hereafter cited as [roll number], M617).

18. Captain Sumner's Report; [Anonymous], "Journal of March," 6/17-18/1845, pp. 164-65. 
mounts into the current and crossed the river to Traverse des Sioux, a trade and mission outpost. Tied up along the bank was "a boat from Fort Snelling" with two brass Howitzers, shells, rockets, provisions, and other items for Sumner's column, but the captain exploded when he found that Snelling's commissary officer had dispatched only 17 of the 31 barrels of flour in his requisition. Sumner later growled, "This mistake subjected my command to great inconvenience, for I was not in a country where it could be corrected by purchase." 19

Resting the men on June 22, a Sunday, Sumner and other officers attended the church services conducted by Presbyterian missionary Stephen R. Riggs. Afterward, Riggs and his wife, Mary, hosted a simple reception and dinner for the officers at their one-room rectory. The next day, Sumner ordered shells and rockets fired "to astonish" the local Sisseton Sioux-a longstanding tactic in U.S. diplomacy with Indians. Every trooper tightly gripped the reins of his mount. The dragoons left Traverse des Sioux "with small regret" on Wednesday, June 25.20

Joining Sumner's command were agents of a different empire. Norman W. Kittson, Joseph Rolette, and Martin McLeod represented the American Fur Company (AFC) in the upper St. Peter's and Red River region. For decades, American fur traders had competed with their British rivals for the Indians' peltries, business, and allegiance in the vast country wedged between the Missouri and Mississippi rivers. The previous year, Kittson had

19. [Anonymous], “Journal of March," 6/14-21/1845, pp. 165-66; Captain Sumner's Report; Fort Atkinson, Return, June 1845, r. 47, M617.

20. Riggs to Mother, 6/23/1845, Traverse des Sioux, excerpted in Mary and I: Forty Years with the Sioux (1880; reprint, with introduction by Rev. S. C. Bartlett, Minneapolis, 1969), 119; [Anonymous], "Journal of March," 6/22-25/1845, pp. 166-67. The country of the St. Peter's River and Red River was generally known to the army. Major Stephen H. Long had surveyed the Red River in 1823, and Joseph Nicolet and John C. Frémont had explored the Sheyenne, Red, and St. Peter's drainages in 1838-1839. See Roger L. Nichols, Stephen Long and American Frontier Exploration (Newark, DE, 1980); and Chaffin, Pathfinder, chaps. 3-4. Sumner had gone north twice in 1844, the second time beyond Lake Traverse. Col. Stephen W. Kearny to Adjutant General Roger Jones, 8/2/1844, St. Louis, K94, 1844, LR, AGO, roll 287, M567; Lt. Col. Henry Wilson to AAAG Henry S. Turner, 10/24/1844, Fort Snelling, enclosure, K139, 1844, LR, AGO, roll 287, M567. Captain Allen had explored the Missouri River drainages to the west. See U.S. House, Captain J. Allen's Expedition, 29th Cong., 1st sess., 1845-1846, H. Ex. Doc. No. 168 , ser. no. 485 , pp. 5, 11. 


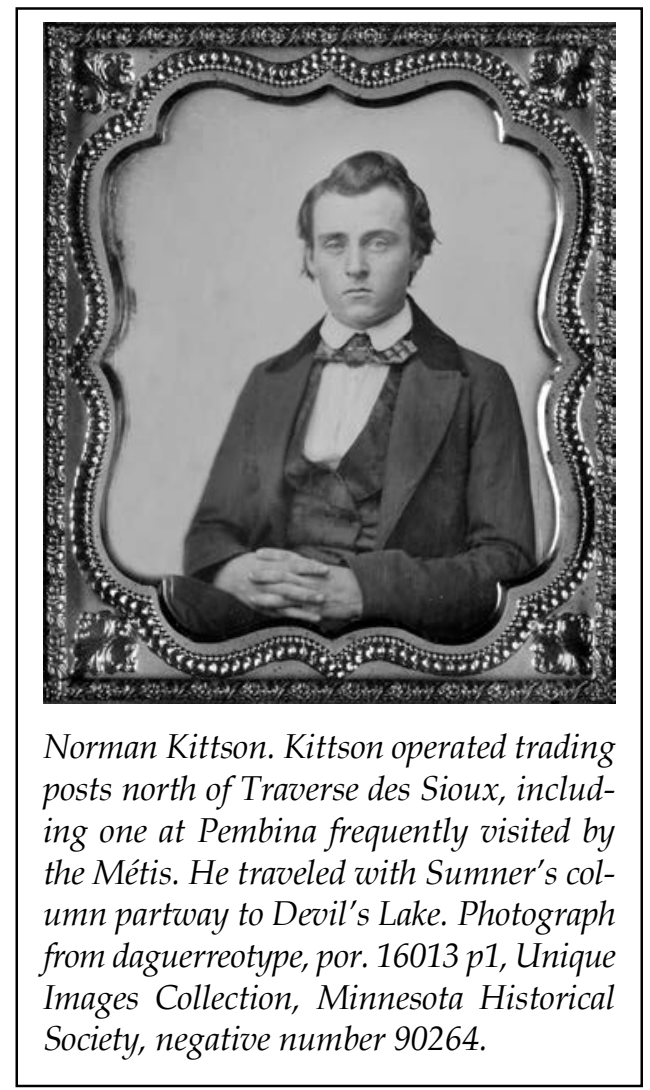

established a trading post at Pembina on the Red River a few miles below the international line. His enterprise directly challenged the monopoly of the Hudson's Bay Company (HBC) of the fur trade with whites, Indians, and Métis in Rupert's Land to the north and disrupted its trade networks into Sioux and Chippewa country below the line. Chafing under the HBC grip, the Canadian Métis, Indians, French, and others illegally crossed the border to exchange their furs, buffalo robes, and pemmican for finished goods at Kittson's station. The Americans' operation worried HBC authorities, who already distrusted the loyalty and stability of the "half-breeds." Real U.S. power, if it mattered in the upper St. Peter's and Red River country, lay in AFC trade networks serving mixed-blood, Dakota, and other peoples, and reaching eastward to Rainy Lake, westward onto the Great 
Plains, and now northward into Rupert's Land. The coming of Captain Sumner's column helped Native and Euro-American peoples to break down the isolation on which the HBC monopoly counted in the Red River valley, and reinforced the MétisDakota peace negotiated by Kittson in 1844, which was so critical to the success of his far northern enterprise. ${ }^{21}$

For three days, the horses and sometimes the men waded through water and mud on the Red River Trail that paralleled the St. Peter's River. Their soggy route led them by Swan Lake and over Beaver Creek. The weather was "remarkably hot," but at last, on June 28, the column began to enjoy "good marching" on firm prairies along the east bank of the St. Peter's. Sumner's dragoons crossed the "beautiful clear" Chippewa River and reached the southeastern extremity of Lac qui Parle on July 1. There they found AFC factor Joseph Renville's trading post and Thomas S. Williamson's mission. ${ }^{22}$

At Lac qui Parle, Captain Sumner held his first "council" with Sioux peoples, the Wahpetons of the Santee division. Hardpressed by white settlement to the east and removed Indians to the south, these Native people, numbering about 400, were impoverished, hungry, and angry. During their exchanges, the captain assured the Wahpetons of the U.S. government's "deep interest in their welfare" and its promise to protect them "so long as they conducted themselves properly and did not wantonly molest the whites." The U.S. government was now "so strong," warned the captain, that "no crime could remain unpunished" anywhere in the "Indian country." After Wahpeton leaders delivered "a few speeches," the captain distributed "a part of the presents," but the Wahpetons' remonstrances led Sumner to conclude, "I do not think the disposition of the upper Sioux toward us [the United States] is very friendly." 23 Sumner's Wahpeton

21. Clarence W. Rife, "Norman W. Kittson, a Fur-Trader at Pembina," Minnesota History 6 (1925), 227-32; John S. Galbraith, The Hudson's Bay Company as an Imperial Factor, 1821-1869 (New York, 1977), 61-64.

22. [Anonymous], "Journal of March," 6/25-7/1/1845, pp. 167-68; Rutland, "Dragoons in Iowa Territory," 168n; Captain Sumner's Report.

23. Captain Sumner's Report. Agent Amos J. Bruce had reported the Wahpeton's hardships to Iowa governor John Chambers on September 15, 1842, St. Peter's Agency, Annual Report of the Office of Indian Affairs (1842), S. Ex. Doc. No. $1 / 7$, ser. no. 413, pp. 427-31. He did so again on September 1, 1843, St. Peter's 
council demonstrated the white paternalism of federal Indian policy, which treated the Natives like unruly children. The captain's stern tone, exercised repeatedly on the journey, was intended to impress on the Sioux and other tribes that U.S. sovereignty was a fact in the upper St. Peter's and Red River region.

The council proceedings - welcoming ceremonies, distribution of presents, and "several speeches" - bored the surgeon's assistant, but Captain Sumner was puzzled when the meeting adjourned. Who "had made the complaint about the inroads of the Half Breeds," he had asked the Wahpetons? They looked at one another, shook their heads, and "professed their ignorance." The captain suspected that the Wahpetons wanted the Métis to "continue to hunt upon their lands" and preferred the British to the Americans. The Wahpetons had "no annuities" arrangement with the United States, and the British government or its proxies, explained Sumner, had been "more liberal in its presents to them." 24

On July 3, Sumner's column resumed its procession over the "prairie" along the St. Peter's. A steady "rain" dampened any festive mood among the dragoons on the Fourth of July, the same day that a special Texas convention assembled to accept the United States' terms of annexation and draft a state constitution. Coming to Big Stone Lake on July 5, the dragoons bivouacked at "Kittson's trading house," the headquarters of his network. "Some eight or nine" lodges of Sisseton Sioux stood "one hundred yards" from the dragoons' camp. The Sissetons, a division of the Santee Sioux, may have been the source of Agent Bruce's complaints about the Métis incursions. In 1842 the Sissetons had lost several hunters to an attack by the Métis, who mistook them for Plains Sioux with whom they had skirmished during buffalo hunts. That vengeance killing may have sparked the unsuccessful Sisseton war party that fell on the cattle drovers and killed Watson. The success of Kittson's new operation at Pembina de-

\footnotetext{
Agency, U.S. Senate, Annual Report of the Commissioner of Indian Affairs, 28th Cong., 1st sess., 1843-1844, S. Ex. Doc. No. 1/5, ser. no. 431, p. 379. Riggs noted that the Wahpetons numbered about 400 when he and his wife, Mary, arrived to open a mission at Lac qui Parle in 1837. Riggs, Mary and I, 54 .

24. [Anonymous], “Journal of March," 7/3/1845, pp. 168-69; Captain Sumner's Report.
} 
pended on keeping the peace between the Sissetons and Métis in the Red River country. 25

Captain Sumner called the Sissetons to a council on July 6 . Among the "chiefs" in attendance were "War Eagle, Red Thunder, and Terre qui Brule." Captain Sumner and the Sissetons knew one another from Lieutenant Colonel Wilson's intrusion to arrest Watson's killers nine months earlier. After admonishing the Sissetons not to "molest the whites," he distributed "the residue of the presents" among them. Labeling the Sissetons "great beggars," the surgeon's assistant noted, "They would like to have had more [gifts] but could not get any more." Scraping by to survive, according to Agent Bruce, these lake Sioux strolled among the dragoons and asked "for a little to eat," but the column's commissary had no rations to spare. Captain Sumner later groused, "I am much inclined to think that the small presents we make to the Indians, do more harm than good, for they serve as a contrast to the very liberal presents they formerly received from the English agents." Why not terminate gift giving altogether? ${ }^{26}$

Native scorn or disappointment obviously embarrassed or discomfited the captain. His few and small presents marked him as ungenerous and unfriendly among indigenous peoples. Gifts were ritual objects with intrinsic power, and their exchange obligated the parties to observe the friendship and responsibilities symbolically represented in the transaction. Sumner's power now resided in the men, musketoons, pistols, and artillery of his dragoon column. The absence of generosity toward the Wahpetons and Sissetons deprived him and his men of the Native vigilance, assistance, and welfare that would have protected the rear of his column far better than a screen of infantry.

The following day, the dragoons crossed the portage between Big Stone Lake and Lake Traverse-the divide between the St. Peter's River and Red River of the North and between the Gulf of Mexico and Hudson's Bay - passed Lake Traverse, and encamped near Polecat Lake. On July 8, as the column moved north toward the Sheyenne River, it encountered a Sioux village,

25. [Anonymous], "Journal of March," 7/3-5/1845, pp. 168-69; Captain Sumner's Report; Rife, “Norman W. Kittson," 227-29.

26. Captain Sumner's Report; [Anonymous], "Journal of March," 7/3-7/1845, pp. 168-69. 
whose chief was "anxious to talk." As Captain Sumner parleyed "in the saddle . . . three of the murderers of Watson" boldly walked "into the council." Sumner later related, "I recognized them at once, and instantly seized them as fugitives from justice." The arrests triggered "a good deal of excitement" among the Sissetons, but the icy captain issued a challenge: should they have anything more to "say," they could tell him when his column returned in a month. With Sisseton prisoners in tow, the squadron stepped off toward the Sheyenne River. Ironically, Sumner had arrested these men at about the same place nine months earlier. ${ }^{27}$

Sisseton boasts raised Sumner's hackles. Their intention, he learned, was to take his "fine horses" and send his men home "on foot." In Sumner's mind, this posturing was simply another expression of Sioux "ill-will" toward Americans. Horse stealing enhanced the honor status of a Sioux warrior among his people but categorized him as a heinous criminal among whites. Sumner ordered his men to shoot any "Indian" found near the herd "at night," and the surgeon's assistant noted that "the greatest care [was] taken with our horses" after reaching Big Stone Lake. At campaign's end, Sumner gloated, "Not an animal was stolen." 28

Sumner's squadron set off on the last leg of its northward journey on July 9. "Excessive heat" prostrated some men; "bad water" turned many bowels to water. Captain Allen got "sick." At the Sheyenne River, reached on the tenth, the men gawked at a Sioux "battle ground" with "horses['] heads laid up in a circle" and with a scatter of equine and human bones. The water was still unpalatable at that point on the river, but the farther the squadron rode north up the Sheyenne, the more the water improved and the men's health rebounded. "Buffalo signs" and the proximity of large herds lifted all spirits by July 15 . The civilians and some officers, Second Lieutenant Alfred Pleasonton among

27. Captain Sumner's Report; [Anonymous], "Journal of March," 6/7-8/1845, pp. 169-70. Sumner's July return does not document his Sioux prisoners. See Fort Atkinson, Return, July 1845, roll 47, M617. With Lieutenant Colonel Wilson, Sumner had gone "thirty miles" north of Lake Traverse to capture Watson's killers in October 1844. Wilson to AAAG Henry S. Turner, 10/24/1844, Fort Snelling, enclosure, K139, 1844, LR, AGO, roll 287, M567.

28. Captain Sumner's Report; [Anonymous], “Journal of March," 7/4-7/1845, p. 169. 


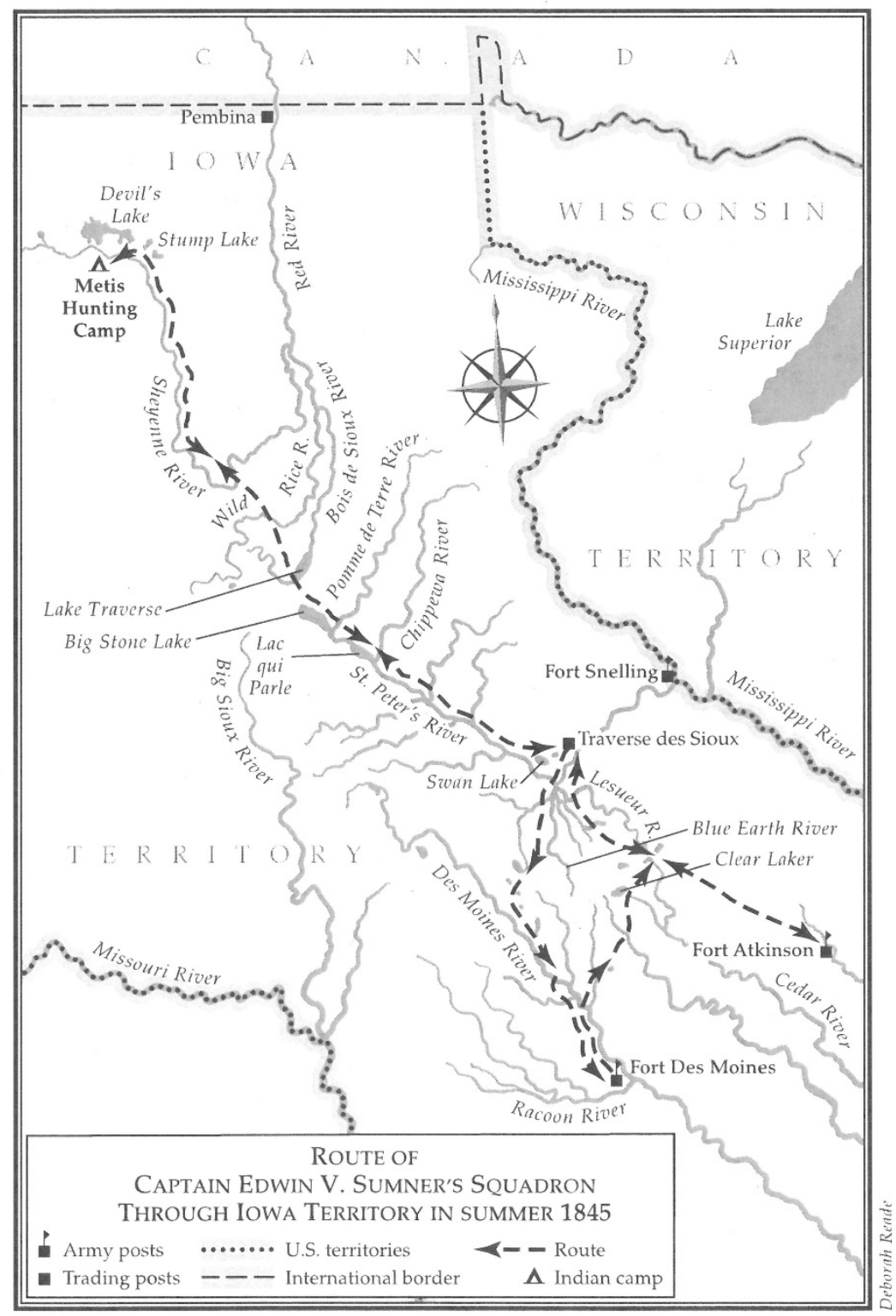


them, gave chase to bison stragglers and antelope. Wolves stalked the column on all sides. When "Mr. Bird," the captain's guide, fired his gun at one, "his horse pitched him over his head." 29

On July 16, as Secretary of State James Buchanan delivered an official "letter" to British minister Sir Richard Pakenham in Washington, D.C., proposing to divide Oregon at the 49th Parallel, Sumner's squadron pushed across the plains along the Sheyenne River toward Devil's Lake. The troopers saw eaten grass and buffalo trails in all directions. In two days, the dragoons "struck the half breeds trail" and bivouacked next to Devil's Lake, in Sumner's words, "at the 48[th] degree of N latitude," his bow to the military and natural sciences. Sumner immediately dispatched "Mr. Bird" to contact the Métis. After dark, Bird returned with "ten of the principal men." The surgeon's assistant described them as "fine large fellows and . . . the best Buffalo chasers in the country." That night a "dreadful storm" blasted the camp, flattened tents, and rained "all wrath" on Sumner's dragoons and his Métis guests. ${ }^{30}$

WHO WERE these so-called "half-breeds"? The Métis were a mixed-race people born of European empire and the North American fur trade. Well-acquainted with them from his service at Sault Ste. Marie and Mackinac on the Great Lakes in the 1820s, Sumner described them as "descendants from the English, Scotch, Irish, and French." He gave no Indian ancestry, but it was Cree, Chippewa, and Dakota Sioux in this region. The Métis now inhabited Lord Selkirk's former Red River colony, Rupert's Land, which had originally straddled both sides of the 49th Parallel. About 1820, the Métis began venturing onto the northern plains to harvest the bison. Twice a year, more than a thousand Métis

29. [Anonymous], “Journal of March," 7/9-16/1845, pp. 170-72; Captain Sumner's Report. Neither Sumner's report nor the assistant's journal indicates that the captain joined the pursuit of the buffalo.

30. Merry, A Country of Vast Designs, 173-74; Captain Sumner's Report; [Anonymous], "Journal of March," 7/17-19/1845, pp. 172-73. These Métis visitors were probably the "ten captains" elected by their people each season to organize and oversee the bison hunt. See Josephy Kinsey Howard, Strange Empire: A Narrative of the Northwest (1952; reprint, with a new introduction by Nicholas C. P. Vrooman, St. Paul, MN, 1994), 302-3. 
men, women, and children-most were Canadian-gathered near Pembina for a massive bison hunt south and west of Devil's Lake. In the early 1840s British and American observers estimated that the Métis harvested over a million pounds of meat during each hunt, much of which they sold to the Hudson's Bay Company in Canada. Those large hunts had triggered intermittent clashes with the Dakota, who were no less dependent on the bison. At the same time, the Métis traded goods and, according to Agent Bruce, alcohol to the upper Sioux. Bruce wanted to end that exchange, but a Métis free-market movement was vigorously challenging the $\mathrm{HBC}^{\prime}$ s monopoly on their trade in furs, robes, and other items. ${ }^{31}$ Keenly aware of their restlessness, Kittson was encouraging the Métis, French Canadians, and Indians to cross the international line to trade their peltries and robes at his Pembina post and his satellites to the east and west.

No storm, even of biblical ferocity, would delay Captain Sumner. On July 17, he sat in council with the Métis leaders. According to legendary HBC agent Alexander Ross, Métis men wore "a common blue capote, red belt, and corduroy trousers" and were "mild," "unassuming," "bashful," "sedate," "grave," and "humble." Their habit of pipe smoking, ubiquitous among them, contrasted with Sumner's abstention from tobacco, but the captain immediately warmed to the Métis, whom he found to be "shrewd and sensible" men. He explained that their "incursions" were "violations" of U.S. "territory" and thus must end. Responding to Bruce's and Chamber's accusations, the Métis protested that "they had no idea of resisting the authority of the American government." These savvy diplomats, while acknowledging their British status, argued that "they were only hunting on the lands of their Indian parents," that their Canadian homeland lacked "game enough" to feed their families, and that this way of life, "followed from childhood," was the only one they knew. Given

31. Howard, Strange Empire, 39-40, 299-306; Gregory Scott Camp, "The Turtle Mountain Plains-Chippewas and Metis, 1797-1935" (Ph.D. diss., University of New Mexico, 1987), chap. 3; Rife, "Norman W. Kittson," 229-30. McCrady, Living with Strangers, 13-15, notes that in the winter of 1844-45, the Sioux and Métis negotiated a treaty after a series of deadly clashes. Kittson had a hand in that diplomacy. 
those conditions, would the U.S. government "overlook" their "hunting excursions" south of the line? 32

A mere captain of dragoons lacked the authority to grant extraordinary privileges. He kindly but firmly held the line: "All governments were rightfully very jealous on these matters." The Métis offered another proposal: What if their people relocated "across the line"? The surprised captain instantly quashed the idea; offering the Métis any "inducement ... to secede as a body" would be "an improper interference with the rights of their government." Would the U.S. government grant a reprieve during which their people "could change their habits," the Métis asked? This suggestion struck a chord. The captain later reported, "After due reflection, I advised them to address a letter to our government, asking as a favor that a year or two might be granted to them in order to give them a little time to commence some other course of life." For a quarter-century, the captain had witnessed the dislocations and destruction of Native life wrought by U.S. and British expansion, and he was not without sympathymaybe even empathy - for their unfortunate plight. ${ }^{33}$

After this initial council, Captain Sumner relocated his bivouac to the "half breed camp" on the west bank of the Sheyenne River. Some "six hundred carts," parked in a huge square, formed an impressive and imposing stockade, and Sumner estimated the band at 600 men. The same number of Métis women butchered carcasses, dried meat, and rendered fat, while clouds of children swirled through the enclosure and among the carts. On July 20, Sumner held another council with the Métis and probably received their petition. Afterward, wasting no time, he ordered his men to break camp and march south. The dragoons and Métis traded "in great style" as the column moved out. ${ }^{34}$

32. Captain Sumner's Report. Alexander Ross lived among the Métis during this period. See his The Red River Settlement: Its Rise, Progress, and Present State; With Some Account of Its Native Races, and Its General History, to the Present Day (London, 1856), 190-91. Agreeing with Sumner, the surgeon's assistant wrote, "They seem a most reasonable and friendly people." See [Anonymous], "Journal of March," 6/19/1845, p. 173.

33. Captain Sumner's Report.

34. Ibid. The surgeon's assistant guessed that " 200 " hunters were present. [Anonymous], "Journal of March," 6/19-20/1845, pp. 173-74. Sumner's estimate was probably closer. According to Howard, Strange Empire, 301-2, the typical Métis 
Captain Sumner, a hard-headed regular soldier, rode away with a favorable impression of the Métis. He admitted that they would return annually: "They know very well that their families and themselves will always be safe with the United States troops, so long as they do not resist them." Ross pessimistically predicted, "There is no earthly consideration would make them relinquish the pursuit [of the bison]." Sumner reported that some Métis were developing a strong economic relationship with the trading post run by Kittson in Pembina, and he had heard unofficially that some Métis planned to relocate from Rupert's Land to Pembina to take advantage of American establishments such as Kittson's. The captain foresaw many "half breeds" becoming U.S. citizens. ${ }^{35}$

UNDER SUMNER'S ORDERS, the squadron "scrupulously" retraced its course to Traverse des Sioux. The irritated surgeon's assistant, who believed that Captain Allen would have explored a new route home, attributed Sumner's choice to his lack of "confidence in his own prairie craft." 36 But Sumner's campaign agenda prescribed flying the flag and showing courage in Sioux country, not exploration and novelty.

As promised, Sumner returned to the Sisseton homeland, encamping at Lake Traverse on July 28 and Big Stone Lake on July 29. Although the Sisseton "manifested but little friendship, they took care to show no hostility." Farther south at Lac qui Parle, the dragoons learned that Private Berry had died after his leg was amputated and that Texas had accepted annexation to the United States. What they likely did not learn is that the van of Brigadier General Zachary Taylor's Army of Occupation had sailed from New Orleans for Corpus Christi, Texas, on July 24 and that Sir Richard Pakenham had rejected President Polk's Oregon proposal five days later. The stakes of North American empire had

hunt in the 1840s brought about 1,500 Métis, of whom 600 were men and the same number, women. The classic account of a Métis bison hunt is in Ross, The Red River Settlement, chap. 18.

35. Captain Sumner's Report; Ross, Red River Settlement, 260.

36. Captain Sumner's Report; [Anonymous], “Journal of March,” 7/21-8/7/1845, pp. 174-76. 
risen appreciably during the squadron's absence, adding substantial military and diplomatic value to Sumner's expedition. ${ }^{37}$

With the weather hot and the ground hard, the squadron covered 20 to 30 miles a day, resting only on Sundays. The column pulled into Traverse des Sioux on August 7. Captain Sumner rested his men and horses the following day. For amusement, some troopers witnessed a Sisseton war dance, but the ever vigilant captain seized a Sioux warrior who had stolen three horses and a mule from Captain Allen's command the previous summer. Incredulous, Sumner wrote, "I heard of this man frequently. He had been running about the country boasting of this feat." A Sioux warrior was supposed to advertise his coup, even livestock theft, but a U.S. officer was obligated to arrest him - to make all the Indians "know that the horses of the government . . . are inviolable, and that they cannot be touched . . . without the certainty of punishment at the time, or afterwards." Lacking any "testimony" against the man, Sumner turned him over to the commanding officer at Fort Snelling, not to the "civil authority," probably for a legal hearing before a military court. ${ }^{38}$

During the next two days, the squadron received provisions from Fort Snelling, and the men lounged about camp and tended their horses. Captain Sumner dispatched his three Sisseton prisoners under guard to civil authorities in Dubuque. His report boasted, "I took these prisoners with me to the end of my march[,] having them in confinement about 40 days." 39

On August 11, Sumner broke up the squadron. Captain Allen took Company I along a route west and then south to Fort Des Moines. The surgeon's assistant sneered, "Captain Sumner true to his route could not desert his old trail, so he took it, knowing before he started it was a very bad one." Sumner pushed his Company B for a week and pulled into Fort Atkinson on August 19. Floundering through swamps, sloughs, creeks, and rivers, Allen's command reached its station at Fort Des Moines on August

37. Walter R. Borneman, Polk: The Man Who Transformed the Presidency and America (New York, 2008), 162; Bauer, The Mexican War, 18.

38. Captain Sumner's Report; [Anonymous], "Journal of March," 8/1/1845, pp. 175-76.

39. Captain Sumner's Report. 


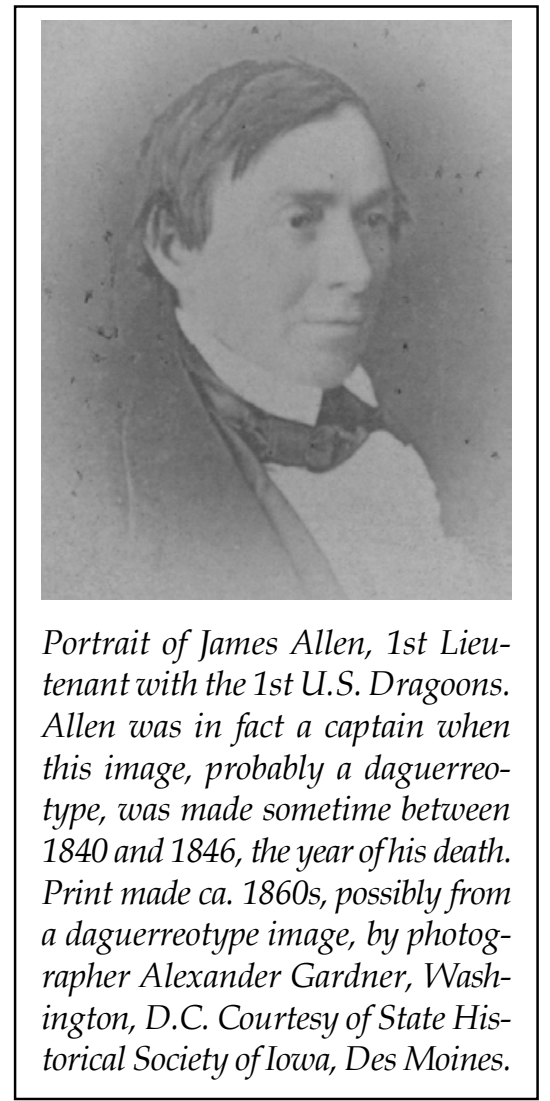

28. 40 Sumner's squadron, his Company B specifically, had traversed about 1,200 miles of Iowa's prairie-woodlands and plains country in 77 days; Allen's company did so in 91.

FOUR DAYS LATER, Sumner reported a successful mission to the Third Military Department. His squadron had flown the U.S. flag in the upper Sioux country, and he had delivered the federal

40. Captain Sumner's Report; Fort Atkinson, Return, August 1845, r. 47, M617; [Anonymous], "Journal of March," 8/11-28/1845, pp. 177-82; Captain James Allen to AAAG Henry S. Turner, Third Military Department, 8/29/1845, Fort Des Moines, A-45, 1845, LR, 3MD, box 3, no. 49, part 1, RG 393, NA. The three Sisseton prisoners escaped again, this time from civilian custody in Dubuque. Riggs, Mary and I, 119-20. Riggs said that Sumner arrested four Sissetons for murder, but the captain said that he took three. 
government's hunting prohibition to the Canadian Métis. During the long march northward, he and Captain Allen had also examined the country between the Blue Earth River and Lake Traverse for the potential site of a temporary "military post." With "but little timber" standing along the banks of the St. Peter's River, only three points offered the "stone," wood, and "rich soil" necessary to construct a post and support a garrison. From south to north, they were the "mouth of the Blue Earth River," "Pattersons Rapids," and "Big Stone Lake." 41

The two captains agreed that Big Stone Lake, the source of the St. Peter's River, was the most suitable site for a post. Richly endowed with "building material, fuel, and soil," the area enjoyed "great salubrity ... from the great elevation and dryness of the soil and country around." Especially advantageous to the federal government was that a "garrison" at Big Stone Lake "would perhaps exert a greater influence on the Sioux Indians than at any other site on the St. Peters R[iver]." Big Stone Lake, and Lake Traverse a few miles north of it, were "places of great resort for purposes of residence and trade" among the Sioux. The garrison would also be "within striking distance of the Chippewas" and the "Half Breeds" to the north and east. Despite their distrust of the Sioux, the captains expressed sympathy for their current hardships, cautioning their superiors that "the establishment of a military post" deep in "Sioux country" would drive away the buffalo, "their only means of subsistence," and thus "cause immediate injury to this people." 42 In that case, the upper Dakota Sioux would have to rely on the generosity of the American people and their government to subsist and survive - a reality that Sumner had witnessed repeatedly from frontier to frontier during his quarter-century of service.

Addressing the Métis threat, Captain Sumner found them far less "formidable" than they had been portrayed. As he explained, "They have no discipline, no capable leaders, and they are hampered by their families. A few regular troops [would] have nothing to fear from them." At the same time, Sumner liked the Métis, clearly preferring them to the Sioux, whom he found unfriendly,

41. Captain Sumner's Report; Captains Edwin V. Sumner and James Allen, Report on a site for a military post above the Blue Earth River, 8/10/1845, Traverse des Sioux, S-45, 1845, LR, 3MD, box 4, no. 49, part 1, RG 393, NA.

42. Ibid. 
unsteady, and unpredictable. ${ }^{43}$ Sumner believed that the United States need not worry about the Métis in the event of war with Great Britain or, more immediately, with Mexico.

Sumner's report, penned at Fort Atkinson on August 23, 1845, aggravated Agent Bruce at Fort Snelling, who objected because it was generally "favorable to the half breeds." Bruce argued that the Métis, upon learning that the United States would soon end their "incursions," had fabricated their claim to the buffalo ranges through ancestral practice. In fact, he claimed, the Sioux had hunted those ranges since "time immemorial." Governor Chambers agreed. These "British subjects" had "at no time resided within our jurisdiction," he reported. Responding to the Métis's petition, Commissioner of Indian Affairs William Medill concurred that the president should "remonstrate to the British government" and suggested that the United States "employ its strong arm," the federal army, to defend its "Indians and others." These lawless "half-breeds" not only slaughtered the "game" but sold spirits to the Sioux in violation of "the intercourse act of 1834." Under no circumstances, Medill declared, should the government indulge them. ${ }^{44}$ Captain Sumner's optimistic and generous views of the Métis gained no traction among the federal Indian bureau authorities and agents, who were already straining to manage Indian populations on the nation's frontiers.

The publicity garnered by the expedition must have been a heady experience for Captain Sumner. Commanding General Scott, in his annual report, devoted a full paragraph - nearly as much space as he gave Kearny's South Pass expedition and Taylor's observation in Texas - to describing Sumner's campaign above the "45th parallel." He praised the captain's "impressive councils or talks with the half-breeds and other Indians who reside within the British line." In three paragraphs, Secretary of War William Marcy boasted that Sumner's dragoons had impressed on "the more restless natives" the long and powerful reach of the

43. Captain Sumner's Report.

44. Agent Amos J. Bruce to Gov. John Chambers, 9/1/1845, St. Peter's Agency, Iowa Territory, U.S. Senate, Report of the Commissioner of Indian Affairs, 29th Cong., 1st sess., 1845-1846, S. Ex. Doc. 1/6, ser. no. 470, p. 489; Gov. John Chambers to Medill, 9/28/1845, Burlington, Iowa, ibid., 481-82; Medill to Secretary of War William L. Marcy, 11/24/1845, Office of Indian Affairs, ibid., 454. 
United States. The Métis now wanted to settle on the U.S. side, he bragged, for the "privilege of hunting within our borders." 45 Although Bruce, Chambers, and Medill likely frowned on the prospect of the Métis settling south of the border, Kittson and other AFC agents foresaw developments advantageous to their trade: weakening the HBC in the Red River region; and expanding the AFC's trade with the Métis, Indians, and other Canadian subjects along the border. Profits and power would accrue to the victor in the economic struggle.

Despite the warm official light showered on Sumner's march to Devil's Lake, his firm "talk" with the Métis failed to stop their spring and fall buffalo hunts on U.S. soil. According to Agent Bruce, the Métis's incursion in spring 1846 exceeded their "usual" number of hunters. Governor Chambers's successor, James Clarke, gave notice that Sumner's mission had failed to deter the "repetition" of Métis invasions. He called their bison hunts a baldfaced theft of Sioux game. Mentioned by name in their reports was the Hudson's Bay Company, to whom the Métis supplied buffalo meat and hides and which was still a powerful force along the U.S.-Canadian border. ${ }^{46}$ The Métis had not weaned themselves from the mother corporation despite their desire, registered with Captain Sumner, to resettle in the United States.

DURING THE SUMMER OF 1845, Captain Sumner pursued his mission along a narrow diplomatic and military front. His intention was to wave the U.S. flag, talk with the Sioux and Métis, and return to Fort Atkinson without the loss of men or horses. As an officer appointed from civilian life, he lacked the extensive education in natural sciences and natural philosophy received by U.S. Military Academy graduates such as Captain Allen, and his narrow focus on the mission left little room for ethnographic recording of Native societies encountered along the upper St. Peter's

45. U.S. Senate, Annual Report of the Secretary of War, William Marcy, 29th Cong, 1st sess., 1845-1846, S. Ex. Doc. No. 1/4, ser. no. 470, p. 197; Scott to Marcy, 11/20/1845, Headquarters of the Army, ibid., 208.

46. Amos J. Bruce to Clarke, 9/1/1846, St. Peter's Agency, U.S. Senate, Report of the Commissioner of Indian Affairs, 29th Cong., 2nd sess., 1846-1847, S. Ex. Doc. No. 1/5, ser. no. 493, p. 246; Clarke to Comr. Ind. Affs. W[illiam] Medill, 10/2/ 1846, Iowa Superintendency, Burlington, ibid., 214. 
and Sheyenne rivers. He appears to have derived special satisfaction from recapturing the three Sisseton fugitives. Successfully transporting them back to Traverse des Sioux and then on to Dubuque added luster to his reputation as a highly capable professional officer.

Probably unknown to Captain Sumner was that the subject of his expedition engrossed the highest levels of government in England, particularly as it negotiated an Oregon settlement with the United States. His squadron's surprise appearance so close to the international border alarmed George Simpson, the Hudson's Bay Company's resident governor in North America. According to Chief Factor Alexander Christie on the Red River, the Métis responded warmly to Sumner's equanimity, and they had talked incessantly of their petition and of settling near Pembina since the captain's departure the previous summer. Meanwhile, Simpson and other HBC executives, who had already been pressing Her Majesty's government for military protection of the company's assets in Oregon, began to lobby Whitehall vigorously for a garrison of British Red Coats at Red River to thwart any American armed or economic invasion and to intimidate anyone who would offer private resistance to HBC authority, such as that practiced by the "half breeds." Indeed, the British government deployed 346 troops to Upper Fort Garry on the Red River in 1846 but withdrew them two years later in the wake of the Oregon settlement and the war between Mexico and the United States. ${ }^{47}$

The impact of Sumner's mission on the U.S.-British negotiations over Oregon is hard to measure. Sir Richard Pakenham's rejection of the U.S. proposal, without forwarding it to the British Foreign Ministry, surprised, insulted, and infuriated the president, who, out of deference to his predecessor, had reluctantly offered to accept the 49th Parallel as the international boundary. Three days after Sumner submitted his report to Kearny on August 23, a miffed President Polk withdrew the U.S. offer and reasserted its claim to all of Oregon to $54^{\prime} 40^{\prime \prime}$, his personal preference as well as his party's. In concert with Taylor's occupation of southern Texas, Kearny's campaign to South Pass, and Frémont's

47. For a discussion of Simpson's response to Sumner's contact with the Métis, see C. P. Stacey, “The Hudson's Bay Company and Anglo-American Military Rivalries during the Oregon Dispute," Canadian Historical Review 18 (1937), 289-95. 
penetration of the Mexican far north, Sumner's dragoon expedition to Devil's Lake was another graphic example of American nationalism aggressively expanding northward and westward into North America. Foreign Minister Lord Aberdeen, who would have settled for 49 degrees, immediately ordered the scoffing Pakenham to express to Secretary James Buchanan his regrets over the rejection and offer to reopen negotiations. Polk believed that British Prime Minister Sir Robert Peel would not wage a war for an Oregon boundary at 42 degrees, although he had dispatched a large fleet to Halifax, Nova Scotia, in response to Polk's bombastic inaugural speech. In the months that followed, the two nations engaged in a great deal of diplomatic maneuvering and negotiation, but the British eventually did settle for 49 degrees in the summer of 1846, understanding that a little less was a lot more in the face of the tirelessly expansive United States. 48

The efficacy of his expedition and diplomacy probably mattered little to Sumner by mid- to late 1846. With the U.S. declaration of war on Mexico on May 13, Company B was transferred from Iowa to the war. While en route to Bent's Fort to join the U.S. invasion of New Mexico, Sumner was promoted to major in the Second U.S. Dragoons. His brigade of First Dragoons assisted Colonel Kearny's occupation of Santa Fe in August. That fall Sumner returned to St. Louis. During the rest of the war, he gallantly commanded the Regiment of Mounted Riflemen and the Second Dragoons in Major General Scott's invasion of central Mexico, earning brevets to colonel. ${ }^{49}$ By the war's end, the Métis were likely a distant, albeit colorful, memory in his frontier service.

\footnotetext{
48. Merry, A Country of Vast Designs, 190; Paul H. Bergeron, The Presidency of James K. Polk, American Presidency Series (Lawrence, KS, 1987), 119-20; Leonard, James K. Polk, 113.

49. Adjutant General Roger Jones to Captain Edwin V. Sumner, 6/6/1846, Washington, DC, vol. 22, LS, AGO, microfilm, roll 14 (Washington, DC, 1965), Letters Sent by the Office of the Adjutant General, Main Series, 1800-1890, Microcopy No. 656, National Archives Microfilm Publications; Historical Register and Dictionary of the United States Army, s.v. "Sumner, Edwin Vose."
} 